UDC 371.14.07

https://doi.org/10.52058/2786-4952-2021-5(5)-36-47

Grigorieva Natalia Anatoliivna assistant of the department of preschool education, Berdyansk State Pedagogical University, str. Schmidt, 4, Berdyansk, 71100, tel.: 0951816204, e-mail: grigorjeva00@gmail.com, https//orcid.org/00000002-7650-4577

Fedorova Svitlana Oleksandrivna 1st year graduate student of Department of Preschool Education, Borys Grinchenko Kyiv University, str. Boulevard-Kudryavska, 18/2, Kyiv, 04053, tel.: 0973165455, e-mail: 15.svitlana.07@gmail.com

Honchar Nataliia Petrivna Candidate of Pedagogical Sciences, Associate Professor, Associate Professor of the department of pre-school pedagogy, psychology and professional methods, Khmelnytskyi Humanitarian-Pedagogical Academy, str. Proskuriv Underground, 139, Khmelnytskyi, 29013, tel.: 0977263214, e-mail: nataly_gonchar@ukr.net, https//orcid.org/0000-0003-1367-0022

\title{
INNOVATION OF PRESCHOOL EDUCATION: FOREIGN PRACTICES AND DOMESTIC EXPERIENCE OF THEIR IMPLEMENTATION
}

\begin{abstract}
The academic paper studies the foreign practices and domestic experience of their implementation in the process of innovation of preschool education as one of the important structural elements in the system of preschool educational institutions of Ukraine. It has been established that ensuring the proper functioning of the field of preschool education is considered as one of the priority state objectives, as an important structural element of providing quality educational services. The statements of scientists concerning the components of the quality of preschool education have been analysed. The management of the quality of preschool education on the basis of national standards and regulatory support has been investigated. The Concept of education development for the period 2015-2025 and the State standard of preschool education have been analysed. It has been established that modern pedagogy reconsiders the issues of upbringing, education and development of personality from the standpoint of analysis of the new socialcultural situation, modern requirements for the personality formation and taking into account the integration of world and domestic science. It has been determined that the main foreign practice in the process of innovation of preschool education is the Montessori Method. It has been revealed that the main principles of the pedagogical process according to Montessori methodology are as follows: availability of a special set of didactic material, availability of rules in Montessori environment, special training of the teacher, freedom of choice, error control, children - active participants
\end{abstract}


in the learning process, maximum independence, and lack of grades and lack of competitive motive. It has been found that more than 20000 schools around the world are currently using the Montessori methodology for children from birth to 18 years old. It has been investigated that the following methods are used in foreign practice of innovation of preschool education, namely: video modelling technique, direct instruction technique, visual cues technique, technique with symbolic games, feedback training technique, random learning technique, model of so-called peer learning, model of psychological and pedagogical support and language training.

Ключові слова: preschool education, preschool educational institutions, innovation, child.

Григор'сва Наталя Анатоліївна асистент кафедри дошкільної освіти, Бердянський державний педагогічний університет, вул. Шмідта, 4, м. Бердянськ, 71100, тел.: 0951816204, e-mail: grigorjeva00@gmail.com, https//orcid.org/0000-0002-7650-4577

Федорова Світлана Олександрівна аспірант 1 курсу кафедри дошкільної освіти, Київський університет імені Бориса Грінченка, вул. Бульварно-Кудрявська, 18/2, м. Київ, 04053, тел.: 0973165455, e-mail: 15.svitlana.07@ gmail.com

Гончар Наталія Петрівна кандидат педагогічних наук, доцент, доцент кафедри дошкільної педагогіки, психології та фахових методик, Хмельницька гуманітарно-педагогічна академія, вул. Проскурівського підпілля, 139, м. Хмельницький, 29013, тел.: 0977263214, e-mail: nataly_gonchar@ukr.net, https//orcid.org/0000-0003-1367-0022

\section{ІННОВАТИЗАЦІЯ ДОШКІЛЬНОЇ ОСВІТИ: ЗАРУБІЖНІ ПРАКТИКИ ТА ВІТЧИЗНЯНИЙ ДОСВІД ЇХ ВПРОВАДЖЕННЯ}

Анотація. У статті досліджуються зарубіжні практики та вітчизняний досвід їх впровадження в процесі інноватизації дошкільної освіти як один із важливих структурних елементів в системі закладів дошкільної освіти України. Встановлено, що забезпечення відповідного функціонування галузі дошкільної освіти розглядається як одне 3 пріоритетних державних завдань, як важливий структурний елемент забезпечення якісних освітніх послуг. Проаналізовано твердження науковців щодо складових якості дошкільної освіти. Досліджено управління якістю дошкільної освіти на основі національних стандартів та нормативно-правового забезпечення. Проаналізовано Концепцію розвитку освіти на період 2015-2025 років та Державний стандарт дошкільної освіти. Встановлено, що сучасна педагогіка переосмислює проблеми виховання, освіти та розвитку особистості 3 позицій аналізу нової соціокультурної ситуації, сучасних вимог до формування особистості та 3 урахуванням інтеграції світової та вітчизняної науки. Розглянуто методику Монтессорі. Визначено, що 
принципами педагогічного процесу за методологією Монтессорі є наступні: наявність спеціального комплекту дидактичного матеріалу, наявність правил роботи в Монтессорі-середовищі, спеціальна підготовка педагога, свобода вибору, контроль помилок, діти - активні учасники процесу навчання, максимальна самостійність, відсутність оцінок та відсутність змагального мотиву. Встановлено, що в даний час понад 20000 шкіл у всьому світі використовують методику Монтессорі у роботі з дітьми від народження до 18 років. Досліджено, що в зарубіжній практиці інноватизації дошкільної освіти застосовуються наступні методики: техніка відео-моделювання, методика прямих інструкції, методика візуальних підказок техніки з символічними ігровими, методика тренінг зі зворотним реагуванням, техніка «випадкового навчання», модель так званого «навчання ровесників ровесниками», модель психолого-педагогічного супроводу та мовного тренування.

Ключові слова: дошкільна освіта, заклади дошкільної освіти, інноватизація, дитина.

Problem statement. Assessing the effectiveness of the activities of preschool educational institutions and the quality of the preschool educational services provided is of particular importance, forasmuch as this component is considered as the main target function of the preschool education system around the world. The implemented and functioning programs for securing the quality of preschool educational services, defined in the provisions of the national policy in the field of preschool education, have a positive impact on the development of the preschool educational sector. The main tendency in the improvement of the preschool education system lies in shifting the priority from the maximum savings in public expenditures in the provision of preschool educational services to the maximum efficiency of using the resources involved, where this approach is relevant for preschool educational institutions in Ukraine.

In modern conditions, the progressive development of the state is impossible without constant improvement of the preschool education system, the provision of which is carried out by employees in the field of preschool education. The principal and defining objectives of preschool educational institutions at the current stage of modernization and innovation of the preschool education system in Ukraine are as follows: creating appropriate conditions for children in order to receive preschool education, ensuring the effectiveness of a personality-oriented educational system, implementation of the principles of democratization, humanization and individualization, integrative pedagogical process in preschool education, which in turn will contribute to the timely formation and comprehensive development of a vitally competent personality of the child, formation of his physical and psychological readiness for a new social role. Consequently, it is important to evaluate foreign practices and domestic experience in their implementation in the process of innovation of preschool education. 
Analysis of recent studies and publications on the problem. The issue of innovation in preschool education based on foreign practices and domestic experience of their implementation is studied by a small number of scholars. In particular, scientific works are devoted to the legal regulation of preschool education in Ukraine (T.O. Lukina, H.A. Hryshchenko); methodologies for assessing the quality of preschool education (H.V. Bodrenko, E. M. Korotkov), approaches to child rearing (N.M. Tarasova, V. Oguz, M. Toran, S. Atli, M. Korkmaz, T. Tastepe, V.H. Dmytriieva, M. Montessori), best practices in preschool education (L.M. Follari), socialization of children with autism (S.D. Rogers), the procedure for teaching in preschool institutions (B. Thompson), where these studies are devoted to assessing the quality of preschool education based on foreign practices that have influenced the innovation of preschool education and ensuring the effective operation of preschool educational institutions.

Formulation of the objectives of the academic paper. The purpose of the academic paper lies in investigating the evaluation of foreign practices and domestic experience of their implementation in the process of innovation of preschool education. In order to achieve the purpose outlined, the following objectives have been identified, namely: in general, to analyse the quality of preschool education in Ukraine in the context of European integration processes; to analyse foreign practices of innovation of preschool education. In the course of the research, general scientific and special research methods have been used, including as follows: analysis and synthesis, comparison, generalization and system-structural analysis.

Presentation of the main material. The proclamation by Ukraine of the vector for European integration has prompted the necessity to determine the principles, methods and procedures for implementing European norms and rules of economic management. Taking into account that education is a defining element of the existence and evolution of the nation, the formation of transformational processes in this area has become a matter of time. In advanced countries, particular attention is paid to the transformation of the preschool education system, which under the influence of scientific, technological and social progress should respond quickly to changes and adapt accordingly [1].

Reforming the education system in Ukraine has significantly affected the country's preschool education system, including the education and quality management system. Leading researchers, characterizing a preschool educational institution (hereinafter referred to as PEI) as an integral dynamic system, propose to consider the quality of the educational process as a purposeful, integrated and coordinated interaction of the monitoring and controlled subsystems in order to achieve the greatest compliance of the parameters of functioning, development of the educational process and its results to the relevant requirements (Figure 1). 

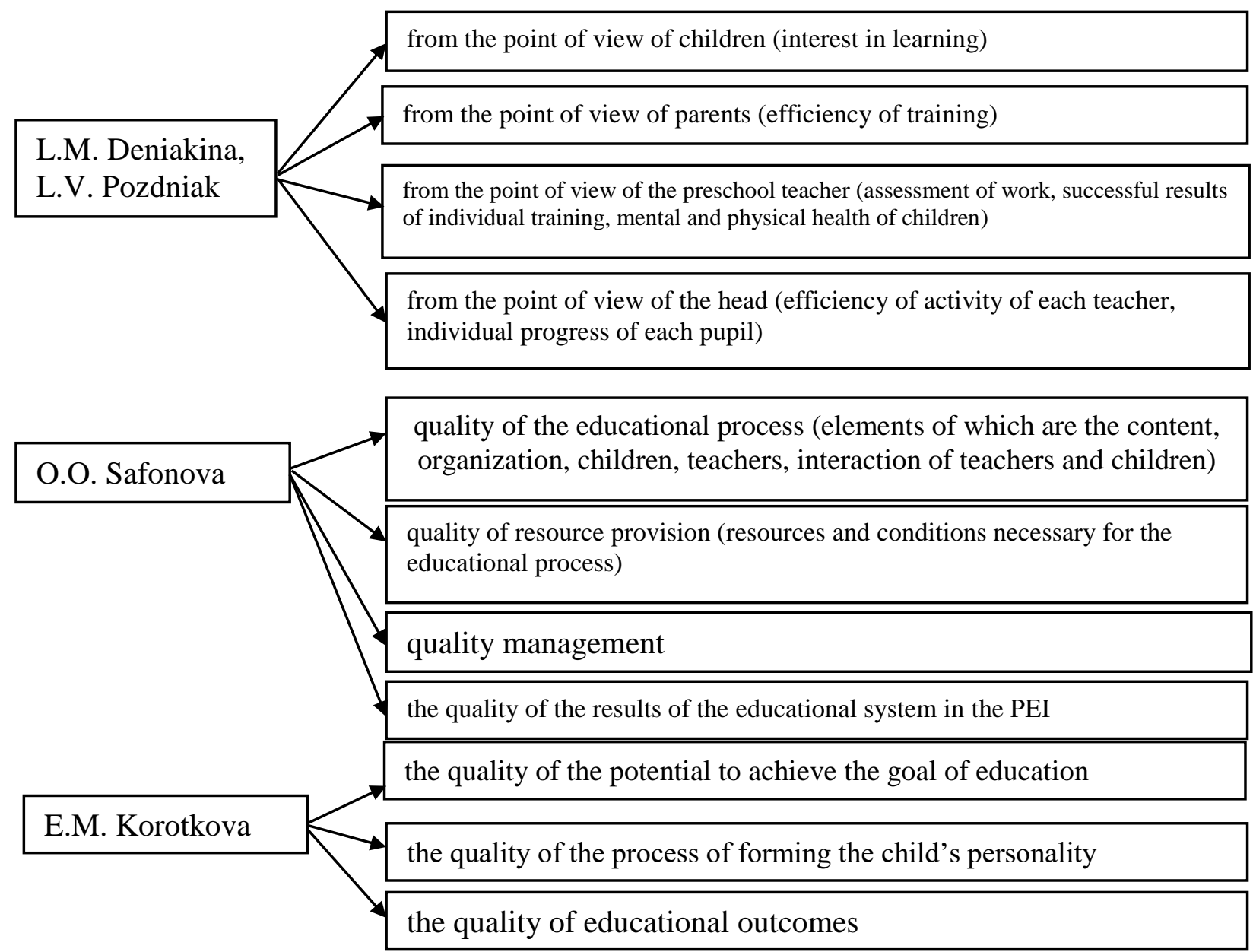

Fig. 1. Statements of scientists on the components of the quality of preschool education

Notes: compiled by the author based on sources: [2, p. $1 ; 3$, p. 24; 4, p. 53].

Consequently, the quality of education in the PEI is the result of the activities of the collective, which is determined by the following aspects, namely: the implementation by the child in the PEI of his right to individual development in accordance with age capabilities and abilities; organization of a high-quality pedagogical process in the PEI (regime, choice of programs and technologies, provision of benefits, a system for improving the professional growth of preschool teachers through various forms of methodological work, etc.); creation of highquality conditions in the healthcare facility (educational environment focused on the inherent value of preschool childhood; positive microclimate in the team; a system for stimulating high-quality work, creative orientation of the team of PEI and its leader; focus on educational needs and requests of the family; systematic collective discussion of the state of the educational process and adoption of competent management decisions) [2, p. 2].

The issue of creating quality conditions for teaching children in accordance with their abilities and interests is proclaimed in the Convention on the Rights of the Child (1989), the European Social Charter (1996), the Constitution of Ukraine and the laws of Ukraine "On Education" [1], "On preschool education" [5], and a number of 
bylaws. Prospects for the development of education and ways to implement it are outlined in the Concept of Inclusive Education in Ukraine [6]. Along with this, a number of relevant documents of the Ministry of Education and Science of Ukraine identify strategic areas of activity aimed at implementing the Concept outlined [7, p. 109].

In order to integrate Ukraine into the European educational space, the Concept of Education Development for the period 2015-2025 has been developed and introduced; it contains a number of objectives to be implemented for the first level of education - preschool education (Figure 2) [8].

\begin{tabular}{|c|}
\hline Implementation of the Concept of preschool education development \\
\hline $\begin{array}{l}\text { access to care and education services for all children; ensuring the } \\
\text { implementation of inclusive education; opening of family-type preschool } \\
\text { educational institutions; legitimization of PEIs; ensuring the acquisition of preschool } \\
\text { education in accordance with age periodization (according to the classification of the } \\
\text { World Health Organization). }\end{array}$ \\
\hline $\begin{array}{l}\text { proper provision of education to children in the areas of social, emotional, } \\
\text { cognitive and physical development, development of language and speech, } \\
\text { development of creative abilities, understanding of the world around them, teaching } \\
\text { a healthy lifestyle. }\end{array}$ \\
\hline $\begin{array}{l}\text { ensuring the variability of educational programs and approaches to the care and education of } \\
\text { children and the principle of free play as a basic principle in the education of children 3-5 years. }\end{array}$ \\
\hline $\begin{array}{l}\text { ensuring equal access to quality education for all citizens of Ukraine, } \\
\text { transforming education into a social elevator. }\end{array}$ \\
\hline $\begin{array}{l}\text { ensuring regular assessment of children's development and learning } \\
\text { achievements in order to evaluate the effectiveness of teaching and learning, and } \\
\text { children's readiness for primary education; ensuring the transition period from } \\
\text { preschool to primary education; development and implementation of a financing } \\
\text { model that will optimally combine public and private investment. }\end{array}$ \\
\hline
\end{tabular}

Fig. 2. Implementation of the Concept of preschool education development for the period 2015-2025

Notes: compiled by the author based on source: [8].

Along with this, the government has approved a new version of the State Standard of Preschool Education dated 21.12.2020, protocol №12 / 1-2, which sets requirements for mandatory competencies and educational outcomes of preschool children (6 (7) years), and the conditions under which positive results can be obtained in accordance with international quality standards of education. This standard aims to ensure the preservation of the inherent value of preschool childhood; establishing the features and requirements for the level of development, education and upbringing of the child; 
insurance of continuity between preschool and primary education [9].

In this regard, modern pedagogy reconsiders the issues of upbringing, education and personal development from the standpoint of analysis of the new social-cultural situation, modern requirements for the formation of personality and taking into account the integration of world and domestic science. The Italian pedagogue Maria Montessori occupies a special place in the humanistic pedagogical movement (18701952). According to the decision of UNESCO, the name of M. Montessori was included in the list of teachers, consisting of only four people who had determined the course of pedagogical thinking in the twentieth century.

Currently, there are kindergartens and child development centers all over the world operating according to the Montessori system. She managed to bring her original theory of free education and development to the technological level and successfully put it into practice. An interesting innovation of $\mathrm{M}$. Montessori was the destruction of the traditional classroom - lesson system and the creation of a new, unique learning process based on the recognition of each student's right to independence, an individual pace of work and mastering knowledge, skills and abilities in a non-standard way [10].

This approach arose in an attempt to improve the cognitive levels of underdeveloped children focused on sensory education and ensured that children with special needs were more successful than normally developed children studying according to other methods $[11 ; 12]$. Its subsequent implementation with typically developed children and the positive achievements obtained at the same time became the basis for its further development, being widespread [13]. In this regard, the Montessori approach has been influential in the practice of teachers for over a hundred years [14].

Maria Montessori connects all these features with the concept of "developing environment" [15]. In this environment, all didactic materials were divided by Maria Montessori into zones, including as follows: the sensory zone, which is responsible for the development of feelings; mathematical, containing materials for the development of mathematical abilities; speech, aimed at language development, materials on space education, the central idea of which is the knowledge of a person in all his diversity and complexity; and a household (economic) area containing materials necessary for exercises in practical life. Within each zone, the material is arranged according to the principle from simple to complex. Each material is designed for a certain level of complexity; however, all together they are interconnected and form a single whole [16].

According to the viewpoint of Montessori, the materials should be used in accordance with the child's anthropology and intended to help in learning about the world and spiritual formation through the appropriate age of development of the child's motility and sensory, the so-called key to the world. In Montessori pedagogy, the central place is given to the child with his individual needs, which play an auxiliary didactic role. The preschool teacher should encourage the initiative and support the ideas of the child when completing tasks from different educational sections [17].

The pedagogical process in the center of development is based on the principles reflected in Figure 3. Currently, more than 20000 schools around the world use the Montessori Method to work with children from birth to 18 years old. For the period 
of more than 100 years of the Montessori system, millions of parents around the world have chosen this approach to education for their children, initiating the establishment of thousands of schools. This, in turn, means that a steady social demand is observed for a paradigm change in the education system [10].

\begin{tabular}{|l|}
\hline \multicolumn{1}{|c|}{ Basic principles of pedagogical process according to Montessori methodology } \\
\hline \hline $\begin{array}{l}\text { Availability of a special set of didactic material. The didactic environment should be fully } \\
\text { represented; it should meet the needs of children of the selected age group. Materials should } \\
\text { be freely available to children, have a clear logic of construction, and meet all the conditions } \\
\text { of the Montessori environment. This principle ensures the comprehensive development of the } \\
\text { child in all areas of mental activity; maximum efficiency of mastering the tasks set in the } \\
\text { materials; interpenetrating logic of Montessori environment construction, when work in one } \\
\text { didactic zone maximally promotes more efficient work in another zone. }\end{array}$ \\
\hline $\begin{array}{l}\text { The presence of rules for working in the Montessori environment makes it possible to teach children } \\
\text { to follow the rules of cleaning after themselves, working on rugs, quietly moving around the } \\
\text { classroom, respect for the freedom of another child. Adherence to this principle implies accustoming } \\
\text { to order; ability to organize one's workplace; ability to use space rationally; ability to be responsible } \\
\text { for one's own choice; the need to complete the action; development of socially adaptive skills and } \\
\text { respect for the rights of others and much more. }\end{array}$ \\
\hline
\end{tabular}

Special training of the teacher allows children mastering the material as quickly and efficiently as possible, makes it possible to gradually master the skills; development of accuracy of perception, concentration of attention; development of the child's memory and the ability to work according to the model; development of logic.

Freedom of choice is implemented in practice by giving the child the right to choose activities, regulate one's own mental activity, independently determining the moments of change of activity and its duration.

Control of mistakes is intended to provide the possibility for the child to see the mistake on his own and to correct it without the help of an adult, which contributes to the formation of adequate selfesteem, the development of the child's search activity, initiative, and self-control.

Children are active participants in the learning process. This principle lies in creating a motivational environment in which children prepare messages on various topics and tell them to their peers. This provides an opportunity for the child to develop self-confidence, independence; meet the need for a sense of significance; to develop the child's cognitive activity, love of learning and the ability to ask questions and answer them, helps prevent fear of public speaking.

Maximum independence contributes to the child's self-confidence, determination.

The absence of assessments teaches the child to adequately assess his own activities; to be independent of someone's assessment; to form a positive image of one's "I"; work with materials only because the child is really interested, not because of fear of punishment or the desire to get a positive assessment.

The absence of competitive motive is one of the stimuli for self-development and self-fulfilment: "Iyesterday" and "I-today", not "I in comparison with others", contributing to the formation of positive self-esteem, favourable image of "I", self-sufficiency, and confidence in the child.

\section{Fig. 3. Basic principles of the pedagogical process according to the Montessori methodology \\ Notes: compiled by the author based on source: [10].}


Scientific investigations on the innovation of preschool education, namely innovative approaches to interaction with children differentiate models of psychological and pedagogical support depending on the definition of target behaviour that should be acquired by the child in the process of corrective interaction [18, p. 400]. In general, the focus is increasingly not on corrective interaction on the part of adults as initiators and facilitators in the paradigm of education, but on the role of the child's peers and their positive impact on the formation of children's social skills. This model of so-called peer-mediated strategies is determined by the ways and to what extent peers influence the formation of the child's personality, who teach him constructive models of social behaviour based on a positive emotional climate. Under such conditions, the function of teachers mentors is shifted towards "pedagogical management" [18, p. 403]. That is, the role of preschool teachers is mainly to properly organize and correct, if necessary, the strategy of "teaching peers by peers". The function of educators and psychologists lies in teaching peers how they can interact with other children in such a way that it helps achieve the desired effect of socialization. It is possible to involve peer - mentors for purposeful pedagogical interaction with children both in the paradigm of preschool and school education, and in the organization of the child's extracurricular life.

Special attention in the approaches is given to the techniques of "incidental teaching", which in the works of researchers $[18 ; 19]$ are outlined as pedagogical methods in speech therapy, occupational therapy, etc. The use of "incidental teaching" opportunities involves the use of natural learning opportunities by teachers, therapists, and parents. In particular, for children, according to the age characteristics of psychophysiological development, playing becomes the central learning tool, which not only gives pleasure and positive emotions, but also develops social skills. In the course of the game it is easier to model and consolidate the desired variant of the social reaction in a native way. "Incidental teaching" during the game enhances children's attempts to behave in the desired way and trains the desired patterns of behaviour.

Another trend in the innovation of preschool education is the correction of the basic response (pivotal response training, PRT), or training with feedback. In the course of applying this technique, a certain model of the child's behaviour is considered as central, basic. Changing the underlying behaviour is believed to affect changing other behaviours without specifically targeting it. Thus, by adjusting the basic model, it is possible to achieve rapid corrections of others - the derived models. It is appropriate to combine this type of technique with symbolic play techniques and language training techniques. This makes it possible to train and expand the child's target skills, enhance positive reactions and reduce the child's dependence on the adult mentor, proportionally increasing the skills of independent social behaviour.

The method of visual cuing system, which is based on the script-fading procedure, is also effective. This is a technology of behavioural analysis that can be used to teach speech and social communication skills, especially for interacting 
children with autism. A script is a word, phrase, or sentence written or recorded on audio media that is used as a model to train communication skills. The main goal of the script fading procedure lies in increasing the number of unscripted social interactions that the participants make during fading and disappearance of a fixed script. When children with autism learn to accurately convey fixed scripts, such scripts disappear, while the number of unrecorded social interactions should increase systematically with the subsequent introduction and subsequent disappearance of fixed scripts. Unrecorded social interactions are defined as expressions other than fixed primary scripts, more than just the use of other temporal forms, such as: verbs, conjunctions, articles, prepositions and pronouns used by a child with special educational needs in the process of speech.

Along with this, in order to increase the social interactions of children in pedagogical practice, video-modelling techniques and direct instruction procedures are actively used [19, p. 451].

Therefore, the priority direction of state preschool education is the formation of a mechanism for state management of the quality of preschool education, the mandatory components of which are the national system for monitoring the quality of preschool education, the introduction of the institution of independent assessment of the obtained results of the functioning of preschool education, etc. The introduction of European standards of quality of preschool education in PEIs of Ukraine should promote continuity between preschool and primary education in the implementation of child development prospects [20, p. 84].

Conclusions and prospects for subsequent studies. On the basis of the conducted research, it is possible to come to a conclusion that in the context of the intensification of the European integration processes of the innovation of preschool education on the basis of foreign practices and domestic experience, their implementation is becoming increasingly important. Ensuring the appropriate functioning of the education sector is considered as one of the priority state objectives, as an important structural element of providing high-quality preschool educational services.

It has been established that the method developed by M. Montessori remains relevant around the world; the system of didactic materials used within the framework of this method contributes to the creation of a favourable developmental environment and the creative development of subjects of educational process. The Montessori system helps fully individualize the process of upbringing, learning and education, and, thus, make it painless for the child's personality.

The importance of the development of the preschool education sphere and a consistent state preschool educational policy focused on obtaining a qualitatively new result in the field of preschool education, has been established, which would correspond to the conditions and tendencies of the world educational society and generally accepted international and European standards in this area. The results of the research can be used to improve preschool education in the context of European integration processes; consequently, this will stimulate innovation and educational 
activities and increase the level of educational services and improve the current quality of preschool education based on the application of foreign practices on innovation in preschool education.

\section{References:}

1. Besh L.V., Dmytryshyn B.Ja., Besh O.M., Jaskevych O.I., Macjura O.I. (2017). Pro osvitu: Zakon Ukrainy vid 05.09.2017 № 2145-VIII // Vidomosti Verkhovnoi Rady Ukrainy, available at: http://zakon.rada.gov.ua/laws/show/2145-19 [in Ukrainian].

2. Bodrenko, H.V. (2018). Upravlinnia doshkilnoiu osvitnoiu orhanizatsiieiu v suchasnykh umovakh yak faktor efektyvnosti osvity ta vykhovannia. [Management of a preschool educational organization in modern conditions as a factor in the effectiveness of education and upbringing]. Zapytannia doshkilnoi pedahohiky. №2. pp. 1-3 [in Russian].

3. Korotkov, E. M. (2009). Upravlinnia yakistiu osvity. [Education quality management]. M: TTs Sfera, 139 p. [in Russian].

4. Pozdniak, L.V., Liashchenko, N.M. (2000). Upravlinnia doshkilnoiu osvitoiu. [Preschool education management]. M. 432 p. [in Russian].

5. Pro doshkilne osvitu: Zakon Ukrainy vid 11.07.2001 r. №2628-III. // Vidomosti Verkhovnoi Rady Ukrainy, available at: http://zakon3.rada.gov. ua/laws/show/2628-14 [in Ukrainian].

6. Kontseptsiia rozvytku inkliuzyvnoho osvity v Ukraini: nakaz Ministerstva osvity i nauky Ukrainy vid 01.10.2010r. № 912. // Vidomosti MON Ukrainy, available at: https://mon.gov.ua/ua/npa/ prozatverdzhennya-kontseptsii-rozvitku-inklyuzivnogonavchannya [in Ukrainian].

7. Lukina, T.O., Hryshchenko, H.O. (2018). Vplyv suchasnykh zmin pravovykh norm na rozvytok inkliuzyvnoho osvity v haluzi doshkilnoi ta zahalnoi serednoi osvity v Ukraini. [Influence of modern changes in legal norms on the development of inclusive education in the field of preschool and general secondary education in Ukraine]. Visn. NADU. Seriia "Derzhavne upravlinnia". №4 (91). pp. 106-115 [in Ukrainian].

8. Kontseptsiia rozvytku osvity Ukrainy na period 2015-2025 rokiv. (2014). Proekt. Available at: http://osvita.ua/news/43501/ [in Ukrainian].

9. Ofitsiinyi sait MON. (2021). Available at: https://mon.gov.ua/ua [in Ukrainian].

10. Tarasova, N.M. (2016). Aktualnist metodu M. Montessori u suchasnii osviti. [Relevance of the M. Montessori method in modern education]. Visnyk Tahanrozkoho instytutu imeni A. P. Chekhova. № 1. pp. 182-189 [in Russian].

11. Oguz, V., Koksal Akyol, A. (2006). Montessori approach in child education. Journal of Cukurova University Institute of Social Sciences, vol. 1(15), pp. 243-256. [in English].

12. Toran, M. (2011). Examination effects of Montessori method on children's concept acquisition, social adaptation, and fine motor skills. Doctoral dissertation, Gazi University, Ankara, Turkey [in English].

13. Follari, L. M. (2007). Foundations and best practices in early childhood education: History, theories, and approaches to learning. Columbus, OH: Pearson Merrill. [in English].

14. Atli, S., Korkmaz, M., Tastepe, T., Koksal Aksoy, A. (2016). Views on Montessori approach by teachers serving at schools applying the Montessori Approach. Eurasian Journal of Educational Research, vol. 66, pp. 123-138, available at: http://dx.doi.org/10.14689/ejer.2016.66.7 [in English].

15. Dmytriieva, V. H. (2009). Metodyka rannoho rozvytku M. Montessori. [Method of early development M. Montessori] /V.H. Dmytriieva. M. [in Russian].

16. Montessory, M. (2006). Mii metod. [My method] / M. Montesori. I. AST [in Russian].

17. Montessori, M. (2007). Antropolohiia. [Anthropology] /M. Montesori. M. [in Russian].

18. Rogers, S. J. (2000). Interventions that facilitate socialization in children with autism. Journal of autism and developmental disorders, vol. 30(5), pp. 399-409 [in English]. 
19. Thompson, B. (2019). The Effects of Behavior Skills Training and Self-Monitoring on Paraprofessionals Use of Incidental Teaching Procedures in a Preschool Classroom. All Graduate Plan B and other Reports, vol. 1406. [in English].

20. Modernizatsiia derzhavnoho upravlinnia ta yevropeiska intehratsiia Ukrainy. (2013). [Modernization of public administration and European integration of Ukraine]: nauk. dop. / Avt. kol.: Yu.V. Kovbasiuk, K.O. Vashchenko, Yu.P. Surmin ta in.; za zah. red. d-ra nauk z derzh. upr., prof. Yu.V. Kovbasiuka. K.: NADU, 120 p. [in Ukrainian]. 